\title{
Social Identities of Children in different Institutional Contexts
}

\begin{abstract}
Summary
Based on an ethnographic fieldwork the article analyses the experiences of 8-10 year old children in three different institutions. It is shown how the children create and maintain different social landscapes in each setting. This means that children's experiences are related to the position they have in the landscape.

The notion social identity is used to discuss and explain these findings. With this notion identity is explained as an interplay between internal and external factors: between group-identification and categorisation. Children's different identities in different settings are not created by children themselves, but must bee seen in relation to the categorisation used by the adults to classify children. The professional categorisations of children are a central part of the social space in relation to which children act, talk, and play.
\end{abstract}

\section{Introduction}

7 his article analyses the relationship between children's experiences and their institutional context. Through a comparison of children's experiences in different institutional settings I will argue that each setting creates different social spaces and thereby different possibilities of social identity for the children. My purpose is to show that to act, talk and participate as a child is closely connected to the social and symbolic context of the setting.
The empirical findings and analyses presented in this article are part of my ethnographic $\mathrm{Ph}$.D. study, which has as its purpose the analysis of interpretations of childhood in three different Danish institutions: A children's ward in a hospital, a school, and an after-school-institution. I have, through a 13 months fieldwork, followed 8-10 year old boys and girls and their professionals through these institutions. The study is based on sociological and anthropological discussions of 'the childhood-paradigm', of which two main theses are that children should be seen as social actors, and that childhood can be viewed as a social construction (see for example James, Jenks and Prout 1998).

According to Berry Mayall, who also studied children in different contexts, the special thing about studying children from a sociological perspective is not that they act differently in different settings and situations. The same is true for adults. Studying children, she argues, is special because of their dependence on adults, and mostly adults with certain knowledge and ideas about children and childhood. Children are always in one or another way engaged in intergenerational relations (Mayall 1994). Every institutional setting with children bears this relationship, and it is here that my focus is placed. 
Analytically I construct 'childhood' as a meeting between three different forms of knowledge (Barth 1989,1995): Children's experience-near knowledge of being a child; adults' professional knowledge about how to teach, bring up and take care of children; and the discursive and collective knowledge in society, which among other things decides the policy of the institutions. In my study I analyse how these 3 levels are connected. At the child-experience level I concentrate on the different perspectives arising when trying to understand what is important for the children at each institution. At the professional level I look at how children are categorised and valued and how the adults, through their practise, communicate this categorisation to the children. At the institutional level I take a short insight to the official documents about the purpose of the institution.

Throughout the article most attention will be placed on the children's very different experiences at school and in the after-school institution. In the concluding section I make some connections with the two other "childhood-levels' in order to show that the perspectives of the children not only inform us about their lives, but also tell us about which ideas of childhood the institutions are practising. This illustrates the social construction of childhood and emphasises that 'the child' is not a universal phenomenon, but a social category which must be understood in relation to place and space.

\section{Children's cultural knowl- edge about the social land- scapes of the institutions}

$\mathrm{I}$

began my fieldwork at the hospital, where I was for 4 months before I went to the school. The school-study took place in a class (3.klasse) with 18 children (8-10 years old) in a big city in Denmark. I followed the children's school day for six months, then gradually expanded the fieldwork to the after-school-institution (in Danish: SFO), where I followed the children for further 4 months.

When I moved from one institution to another during my fieldwork, I had to ask myself every time: What is it that these children know about the life here, that I don't know? I was often surprised at how easily they changed behaviour in relation to the setting they were in. For example at the hospital Carina was very quiet when doctors and nurses were in the room, but in relation to me she was lively and open, asking a lot of questions and in the hospital-school she was protesting frequently in opposition to her teacher. I wondered how and why the different professionals (both the nurses, the teachers and the pedagogues) during her stay came to an agreement on Carina's personality, while I saw more and more different Carinas. I had several of these experiences with the children, as McDermott describes his Adam (McDermott 1993): At school you never heard or saw Mikkel, but in relation to me he had a lot to tell, and when observing him at the after-school institution, I wrote in my diary: "Is this the same boy as the Mikkel in school? - I can't recognise him. He is playing football and acting and shouting as I never saw it in the schoolyard." Time after time I thought, that I had grasped the norms and conventions which the children organised their life around, and time after time I had to admit, that I was incompetent in my 'feel for the game', as Bourdieu puts it. At the hospital I couldn't see gender for instance, but when entering the school there was gender-separation everywhere. I then thought that I had not been clever enough to investigate this at the hospital, but following the same children to the after-school institution, I was surprised yet another time. Girls and boys who in school said that they hated 
each other and who would not engage in any common activities there could often be found in the after-school institution playing and chatting together.

When I asked the children in the different settings if they could tell me about the rules here, I always got very detailed answers about where children are allowed to be, what makes the teacher angry or which rights children have or do not have. Two boys explained to me at the hospital: "You are not allowed to leave the ward, you can't enter the office, and you have to be very quiet here." "Did anyone tell you?" I asked. "No, do you think we are stupid? We just know!" was the answer. It is this 'knowing' how to move, behave and orientate oneself in each setting I tried to follow.

During my fieldwork the children often reprimanded me, when I did not follow these implicit rules: "You can't put your jacket there" some girls told me on my first school day. "That's the boy's rack." When playing table- tennis I was instructed to shout at the player who won, and in the after-school-institution I was told that girls only can use the boys' toilet when it's not school-time. The children had a knowledge of implicit rules and norms that I often lacked. Their social life was not spontaneous and their play was not totally 'free'. Something organised their activities and mutual relations - and this tacit organisation changed from institution to institution. The focus of my participant-observation was to grasp parts of this cultural knowledge (Hastrup 1992).

Obviously the children shared a knowledge about the elements in these processes. But this shared knowledge did not mean that they used their knowledge in the same way. In other words, children's experiences cannot be represented from one position, called children. What the children also knew was that norms, rules and rights are distributed. Some children can act, talk and break the rules when others cannot. It is this distribution that differs from setting to setting. When Jannie told me about how to play table tennis in the right manner, it is worth noting that she never played the game herself, only watched. When 8 year old Sara told me at the hospital in detail about her heart disease, and I expressed surprise at how well-informed she was, she answered: "Nobody ever told me. But I usually don't tell what I know to any adults. They don't think, that I know about it." When I observed that Mikkel was mostly quiet at school, or Carina was the same at hospital, but they both had a lot to tell me about life and things there - it was not because they did not have the ability to talk or reflect, or because they had a very personal relationship with me. They just knew that not everyone can talk, ask or say what they want everywhere. They knew when to show and use their knowledge and when not to. This is not only a matter of individual differences or choices, or only a matter of being positioned as 'child'. Every setting showed a distribution of children, a social landscape of different categories of children.

In order to analyse and explain this phenomenon I have used the notion social identity (Jenkins 1996). Identity, viewed from this theoretical perspective, is a social process. This means firstly, that it is based on social relations, and secondly that it is changeable. In addition, it has two dimensions: an internal dimension, which is based on group-identification, and an external dimension, which is based on categorisations defined by others (ibid). Using this notion to analyse the fielddata, it becomes important to look at the children's cultural knowledge as knowledge of how to create, maintain and separate groups. In the following section, I will describe some typical group-processes from the internal perspective of the children. The first part describes children's experiences at school and the next part follows the children at the SFO: 


\section{Being a school-child: three typical perspectives}

$\mathrm{T}$ he teacher had asked the children to do push-ups for two minutes in order to increase their heartrate and afterwards to count it. A large group of girls did the push-ups lying on the floor close together. They did the exercise in time with each other and counted the numbers loudly in harmony. Thereby they finished at the same time, and said to the teacher: "We got 77".

The boys on the other hand, did not say anything, but worked intensively one by one. Afterwards most of them shouted to each other: "I got 80, how many did you get?" And a quarrel began about cheating with the counting, and who was the fastest.

A first impression of this scenario is that the class is divided into two groups: boys and girls. But there were also boys and girls who didn't say anything, did not quarrel and did not do push- ups in time with the others.

This 3-parted division of the class was very typical: girls, boys and outsiders. This division, was not only around the genderboundaries but also around being popular or not. I shall in the following describe each of them.

A gender-perspective - belonging to the girl's group:

Most of the girls defined themselves explicitly with gender, and this definition was often used to focus on and maintain equality. Therefore when doing push-ups they did not compete, but did the same number. The "We - got 77" referred to the sameness and this 'we' was often used to explain things to me about school-life, or to explain differences between groups, as in the following example: The class had been outside doing experimental mathematics. Four girls had finished quickly and were asked by the teacher to go to the class and continue with written mathe- matics. Tom entered the room and said to them: "I don't understand how you can be bothered to make extra mathematics". Katrine answered him: It's because it's only girls who feel like doing that, boys only want to make noise and trouble."

The boundary around this group was defined by separating, verbally and bodily from the boys. From this perspective the world was divided into 'us' and 'them' - girls and boys. These girls seemed to have a mutual silent contract to fight against boys at every possible moment, as in a PE lesson where all the children were standing in a circle and playing 'tik', a game where you must catch each other. When a girl was the leader she only chose girls as the next leader until the game broke down because the boys started to protest against their exclusion. During lessons when asked to divide in groups, the girls would always make girl-groups, and protest loudly if the teacher forced them to make groups of both boys and girls. During the fieldwork I too was drawn into this girlworld because of my sex, with lots of instructions about where to sit and who to play with in the breaks, as Maria told me: "You are a girl, then we shall play together in next break." In the lessons these girls could manage to communicate silently with each other with signs and small letters behind the teachers back. They were very much aware of the rules of being in the class-room without disturbing, but that did not mean, that they didn't do other things to avoid boredom. As Maria explained to me: "I can look like I am thinking of mathematics (then she shows me how to count on her fingers) but in reality I am thinking of Spice Girls."

\section{An individualistic activity-perspective - belonging to the boy's group:}

Another group was defined explicitly around interests and knowledge, especially about football, computer-games and video-films. 
This group was made up of boys, but they did not define themselves in terms of gender. Here you are not 'we' but 'I'. The group was tied together by a common focus on the group-member's abilities and courage to compete with each other - to show each other your individual differences.

In any given break these boys played football and once I tried to become a member of their team. In the process of negotiating my possible membership, I was not evaluated by my sex, but for my abilities. Among the boys there was a discussion about whether I could play, and they allowed me to participate as a goalkeeper because I once had been a handball keeper. The few times I was allowed to play, I learned that while walking off the pitch you had to evaluate each other and to choose who played the best, and often I was asked: "Who did you think was the best player today?" I had to suppress my (adult or girlish?) desire to say that 'they were all just as good as each other.' Instead I had to train and learn how to evaluate good kicks and tackles.

These boys were acting more like individuals showing each other their personal qualities. There was a daily exchange of information between members of the group about sport-results and the latest videos. This was also the case during lessons, with no attention to the teacher's demands for silence and without considering the rest of the class. Their individual interests and immediate commitment seemed to be of first priority, while being told off did not seem to bother them. The experiments in a science-lecture could absorb them completely, as could the musical instruments in the music-room, even though the teacher would be asking them to sit still, wait for further instructions or stop talking.

As Berrie Thorne points out, this picture of boys and girls seems like a stereotyped presentation emphasising gender difference.
She believes that these two perspectives are variations of the same story: Different ways of acting as a popular child (Thorne 1993) or I would say 'pupils'. There are other children in the classroom, and they do not divide themselves into gender-groups. They are simply without group-attachment.

\section{A 'loner' perspective - being a silent observer:}

This third perspective in the classroom, was from what I call 'the silent observers' or who in other studies are called 'the loners' (Corsaro 1997:157). They were both girls and boys and they did not relate to each other as a group. Their experiences, however, were not individual, but had many common characteristics, showing a common consciousness of their position. Often Mikkel told me: "Do remember to write in your book, that I have got no friends." In this way he told me that he stood outside the group community. These children were, according the children's own accounts, excluded for different reasons. In relation to the boys, it was with the argument that "he hasn't got football on his brain". Concerning Jannie the other girls said that "she preferred to walk alone". According to these girls, Jannie did not accept being a member of the girls-club.

It was these children who showed the most interest in being interviewed by me and I often was surprised by their reflectivity, flow of words and knowledge about the social life and its implicit rules. Especially because these children most of the time at school were silent, when they did talk, they spoke quietly. In relation to the teachers they were never told off, perhaps because these children never disturbed the class by shouting, talking, moving around or engaging in inappropriate behaviour. Throughout the interviews I perceived that they were very much aware of the implicit rules, both in relation to the other children and their teachers, but this know- 
ledge did not make it possible for them to act, talk and participate in the same way as the other children. Another common characteristic of these children was that they needed extra help either from the teacher or a specialneeds class. Mike reflected on this in a way that showed that according to him you can't both be in need of extra help AND be a pupil, who is wild and gets told off at the same time: He said: "I'm not wild, I don't get told off. But I get a lot of help."

With these short insights into school-life from children's perspectives I want to emphasise that being a child in this institution is very different depending on which angle you are looking from. In this class, three perspectives dominated and this distribution of children determined the different ways of organising activities and relations both with peers and with teachers.

\section{Being an SFO-child}

$\mathrm{T}$ The interesting thing is that when following the same children across the corridor into another institution - in Danish called SFO (school-free-time-arrangement), the distribution of children changed. There was a different choreography for the activities, with about 125 children aged from 6 to 11 years old being together in 5 different rooms with 2 pedagogues in each. Most of the time, however, the children used the whole institution, the playground, the kitchen and the different activity-rooms.

The children explained the SFO to me in the following terms: "Here the adults cannot force us to do anything." - "We can decide ourselves what to do". "We have to play here". "At school the adults decide everything - in the SFO we ourselves decide what to do".

These headlines of free choice and free play however, did not mean that what the children did at this institution was without structure or rules. Hilde Liden notes in her study of children in the same type of institution that it is often taken for granted that children's free play is chaotic and in opposition to the structures made by adults in order to organise children's lives (Liden 1994). But when adults do not structure the time and space of everyday life, children make their own ways of organising their social life, argues Liden (1994). I will add that this organising at the children's level is not only the children's own work, but has to do with the social space in which this takes place.

But firstly, we have to look at how children at an SFO organise their everyday life. Following the children from third grade, I was at the beginning of my fieldwork very confused. Life at the SFO seemed without problems; more than 100 children moved around in the institution, playing, shouting, laughing and walking around in small groups. I saw adults playing together with the children and many different types of activities taking place at the same time. You could bake in the kitchen, roll on rollerskates, go to the swimming pool, look at videos, play table-tennis or football and lots of other things. Obviously the choice was 'free', nobody had made plans for the children except for two daily arrangements: children had to stay outside for half an hour just after school-time, and they had to participate in an 'assembly' in their particular room to eat at two o'clock.

I spent a long time wondering how the children here worked out what to do and who to be together with, since nobody told them. Should one choose playmates and activities from the beginning every day?

Being together and attached to a group seemed to be a fundamental way of being in the SFO for the children, but how were these groups decided and maintained and what was their inner content, I asked myself? From my field-material I identified 4 differ- 
ent forms of groups in which the children from the third grade were involved:

In friend-groups it is decided beforehand who to play with. What to do in this group is not the most important thing. As a girl explained to me: "We are always playing together the four of us. What we are going to do together - well, we don't decide, it just comes to us". When following these 4 girls in the institution I saw, that they were able to maintain their group wherever they were, and they could change activities from moment to moment. But they never invited other children into their group.

Another form of group had common interests for a game as a focus, such as football or Spice Girls. Children who had the abilities, knowledge and interests in this activity were members and they were aware of this. Therefore they did not need to make appointments with each other. When one or two started the game, the other potential members of the group would show up and join in without negotiation. They were accepted in advance. This group was maintained by two types of activities: playing the game (football, or being a music-group for example) at a certain place in the institution, and exchanging knowledge, photos and news about their idols whenever they met during the day.

These two types of groups were normally either all male or female, whereas the two following group activities could be arranged across gender-boundaries:

The spontaneous activity group was often arranged at school in the morning, as Ina and Marie did in a break where I heard them arranging a treasure hunt for the boys the same afternoon. When I arrived later at the SFO, the two girls were together with two other girls planning tasks for the boys. Two days later both girls and boys were engaged in this hunt, and afterwards they continued to set up other competitions.
Another day I found both girls and boys from the class sitting close together in the playroom in a coach talking about love. Afterwards they began to play hairdresser, continuing for the rest of the afternoon to create fancy hairstyles for each other - both girls and boys. To exclude other children from this kind of group, the children often chose rooms and places at the institution that were defined as 'private space' - for example in the playroom where the children were allowed to lock the door, or behind the little wood outside, where adults seldom came. This signal were understood by all the children.

The last form of group among these children was created around a common condition - perhaps boredom or being restless. Again, the use of space in the institution was a signal to the other children about how stable the boarders around the group were. Both boys and girls could hang around in small groups, typically in the areas with a lot of traffic moving up and down the corridors. It looked as if the inner meaning of these groups was: Let's see what happens. These groups could be interrupted and changed without conflict, which suggests that the boarders around them were very unstable. You could meet somebody, and they would perhaps invite one from the group to play table-tennis, and so the group would be broken up.

These examples show that the children managed different forms of being together and that they knew how to create small islands in the institution where 3,4 or 5 children could play together without being disturbed by the other 135 children or the adults.

But through the fieldwork and the following analysis it became increasingly clear to me, that this was only one perspective of being a child in the SFO. And again this is the perspective of the popular children, the chil- 
dren with the most power and possibilities to act and negotiate with the adults, which they did daily, for example, by protesting against the rule of 'assembly'.

That the SFO was experienced from other perspectives was hidden to me for a long time, because I only followed the 8-10 year old children. But by becoming aware of how the children valued play-things and spaces in the institution, I came to see that the 8-10 year olds, or more correctly 'the children from third grade', held a special status in the institution. And I realised that most of these children did not include younger children in their groups.

When I spoke with the children about the SFO, it was often repeated to me that the funny thing about SFO is to 'have' the playroom or the swings for example. "It is fun being here when I get the swings." With this little word 'to get' a thing, I became aware of the daily silent fights in the institution to get these things and the different techniques used to occupy a room, a bicycle or a swing, since 140 children could not all have the same popular play thing. To be the first, to be many wanting a thing, or to hold things for each other were some of these techniques. But the easiest way to 'get' a thing or occupy a space was simply to be a child from third grade: The oldest children in the institution. Eva explained this to me when I asked her how to get a swing: "The big children can always have one. We can always force the smaller children to leave." Over the following days I observed that she was right. I some times placed myself near the swings in order to find out how to get one. A typical situation:

Four third grade girls from the friendgroup came running to the swings. One was free, so Eva started to swing. The other three girls were running around her, chatting and laughing. Smaller girls were swinging on the other three swings. When the friend-group entered the area, the smaller girls stopped their activity and watched. One left her swing silently and Caroline - another girl from the friend-group - took over. These 4 girls never stopped their activity to watch the smaller girls.

Being an audience was a typical role for the smaller children in relation to the children from the third grade. When the SpiceGirls group, for example, was doing their training, chairs were arranged for the audience, which mostly consisted of younger children. These 6-8 year old children did not use the institutional space in the same way as the third grade children, and in relation to the adults they were not negotiating and protesting as the older children were. Often the youngest children were sitting around a table in the room with a pedagogue, making drawings or cutting with scissors. In the playground the younger boys never entered the older children's football area, but stayed in their own smaller pitch.

After these analyses I now understood better why Mikkel at the SFO was different from the Mikkel at school, as described earlier. At school I have described him as one of the 'silent observers', in need of extra help and outside the popular groups during playtimes. The earlier example where I observed him at the SFO was while he was playing football: but it is worth noting that he did not play on the football pitch where children from third grade normally played. He played with the younger children. And in relation to them he - in this institution - had the power to shout, run and be the leader of the team. And this is perhaps why I never saw Jannie and Mikkel playing together with their own classmates, but seeming to prefer playing with younger children.

The SFO seemed to offer more possibilities for the third grade children to engage in different group activities. The popular children did not make two groups with strong 
boundaries as they did at school, but seemed to make more flexible groups. The loners from school were still excluded from their own classmates, but had status in relation to the younger children. According to these experiences at the children's level, a central, but tacit principle of organisation in the SFO was that of age. The talking, acting, protesting, negotiating and occupying-things, and -space were reserved for the oldest children.

\section{The external dimension}

$\mathrm{T}$

The children's experiences show that each institution has tacit rules which distribute the children into a social landscape of differences, split them up into groups and loners and make distinctions between who has status and who has not. Or who is competent and who is not. Who can talk and act and who cannot. The analyses of the fieldwork at the hospital concludes, like many other researchers have found (see for instance Davis 1982, Aldersson 1993, Mayall 1994, Bluebond-Langner 1978), that the hospital setting does not show many variations in the social landscape of the children. It seems as if only one position is possible: Being incompetent, silent and unknowing.

My argument is, that these different forms of social organisation, of having status or not, cannot in isolation explain the characteristics of children. Even though the children at the SFO describe themselves as 'free' to decide, what they want to do, this is not totally 'self-government'. The children refer to a 'we' and thereby to a collective understanding (Corsaro 1997) and not to the possibility of individual choices: they don't say 'I' am free to decide, but say 'we'.

To understand the different social identities that the institutions offer the children, it is necessary to include the external perspective (Jenkins 1996), represented here by the professional adults. To explain their role in relation to the children I will refer to Bourdieu's concept of 'social space'. According to Bourdieu, your position in the social space has to do with which kind of official acknowledgement you possess, in his terms 'symbolic capital'. Thus in a social space you have value-systems which define how groups are related, their mutual power relationship and the actors' right to speak. These value-systems are built upon official allocations of acknowledgement; a diploma and a good mark are examples of allocation of symbolic capital. Actors in the space, having the most symbolic capital, also have the most power - which among other things means that they have the right to define categories in the space (Bourdieu 1990). This categorisation is communicated to the children throughout their daily practise. Teachers and pedagogues possess the official authorisation to allocate acknowledgement to, and take it away from the children. This happens daily in public - by praising them, giving them awards, telling them off, deciding sanctions and punishment, giving or taking rights, making rules, deciding who can talk, and so on. The children are judged in public according to their behaviour and - especially at school - also according to their intellectual performance. These judgements are not only supervised by the adults' individual knowledge about children, but are related to the professionals' institutional duties, their educational background, collective and personal understanding of childhood and the institution's official ideas of what the purpose of working with children is. When investigating, by interviews and observations, how the professionals administered this knowledge, it is striking how closely the children's experiences of different social landscapes correspond to the professionals' ascribed values or capital.

At school I asked the teachers if they could identify any groups in the class. They 
then divided the children into three groups, identical to the perspectives which I described from the children's level: girls, boys and 'the weak children' as the teachers called them. A female teacher said to me: "There are the children with abilities and willingness. Then there are the children with abilities, but without willingness. And thirdly there are the children, who have the willingness to learn, but not the abilities". In her value-system, two criteria were important: Ability and willingness. In the teachers' practise in general, you could find these values as a foundation for the public distribution of capital to the children. The girls, for example, were often given positive attention because of their good behaviour. The teacher used their obedience as a good example and often placed the girls in the classroom between some boys to help quieten them as seen, for example, when a teacher said to Katrine after a boy complained that she hit him with a pencil: "I understand you, Katrine, he is in fact intolerable". The "unwilling' boys were often told off, excluded from the classroom or isolated on a singleseat. But, on the other hand, they were often praised for their schoolwork like the girls, and in addition they enjoyed a more implicit acknowledgement from the teachers, who in fact liked the boys being a bit naughty and wild. "It would be boring to be a teacher if everybody were like girls" a teacher told me, and added; "The Danish school-system should not be like the English with all that discipline". Often the male teacher during lessons referred to the 'old days' with funny stories, emphasising his own role as 'rulebreaker'. So if you just show some intellectual abilities, it is OK for a boy sometimes to be a rule-breaker - that seems to be the signal, that the teachers communicate to this group. The third group, with learning disabilities did not receive much capital from the teacher, even though they did not break the teachers' rules of good behaviour. They were not used as good examples for the noisy boys, they were not praised in public for their willingness. And when the teacher distributed praise or reprimands for good or bad spelling or counting, they were not even mentioned.

At the SFO, the children's abilities to learn were not an important value. Here the pedagogues expressed freedom (in opposition to schoolwork), being happy and playing without adults nearby as important. A male pedagogue explained to me: "Modern children are too much kept under surveillance. Therefore we have made a lot of space for the children, where they can be themselves." The pedagogues often referred to their own childhood with examples of the mother 'just being there' but not interrupting, and comparing the institution with a 'home'. Free choice and independence from adults were central and often cited values.

As in the school, these values were ascribed to the children in a way that reflects the division of children I have described, separating the big from the small. During the interviews the pedagogues often referred to 'big' and 'small' children. When I asked them what separated the two kinds, they always gave me answers including independence, as in this statement: "I like the oldest children the best. They only come to us if they need help. But most of the time they just play themselves. And in this institution, they can be totally themselves."

The pedagogues used other techniques than the teachers to communicate their valuesystem to the children. They seldom told the children off, and made only few explicit rules for proper behaviour. But they gave the children from the third grade more rights in the institution, more responsibility and were not watching them as much as the smaller children. These children, for example, had a daily duty to make toast for the rest of the in- 
stitution (a rule which the children did not protest against). And the adults arranged meetings, especially for the third-grade children, where they could express their wishes about forthcoming arrangements. Parallel to this, the adults accepted the oldest children's right to decide for themselves. Ken, for instance, always made his own toast when he was hungry. And these children often succeeded in their attempts to avoid 'assembly'. I once asked the manager of the institution if he had ever thought of making rules for how to get a swing, or other popular things. He answered: "Well, we don't need to. The small children will be big - as time goes by." In this institution status (and independence) come as a natural thing - as you grow up, while status at school is something you fight for and deserve.

\section{Putting the study into perspective}

urrently there is a public debate in
Denmark about how to create con-
nections between the different expert systems and institutions which have children in their care. The official argument is that children need a more coherent daily-life. Within the school-system there is a historical change on its way, where schools and afterschool institutions are going to be united called the 'unified school'.

It is not clear, however, whose need this $\mathrm{co}$ herence meets. Obviously it is a need formulated by adults and not based on research trying to understand the children's experiences in the institutions. According to my study, some children can use the different social contexts of the institutions to change their social identity, to gain more status and thereby have more possibilities to act, talk and participate in social relations. We need more research that focuses on children's experiences and cultural knowledge in relation to place and space before we can know if the unifying of institutions is better for children. At the theoretical level we also need more debate about how to interpret the changing social identities. Does this mean that childhood is a purely relative phenomenon? And does it mean, that children only act in relation to external categorisations imposed on them? The study reveals a need for further discussion about the connection between the internal and the external dimensions of social identity. In a time when the diagnosis of children is a daily occurrence in the media debate and professional practice, this study points to a need for research into the extent to which the professional ways of categorising children affect children's possibilities to develop their own identity.

The article is based on a paper presented at the conference: "From Development to Open-ended Processes of Change", Institute of Anthropology, University of Copenhagen, April 6th-7th 2000.

\section{References}

Alderson, P. (1993): Children's Consent to Surgery. Open University Press, Buckingham.

Barth, F. (1989): The Analysis of Culture in Complex Societies. Ethnos 54 (3-4).

Barth, F. (1995): Other knowledge and other ways of knowing. In: Journal of Anthropological Research, vol. 51.

Bourdieu, P .(1990): Socialt rum og symbolsk magt. Oversættelse i: Callewaert et al (red): Pierre Bourdieu. Centrale tekster inden for sociologi og kulturteori. Akademisk Forlag.

Corasaro, W. (1997): The Sociology of Childhood. Pine Forge Press.

Davis, A.G. (1982): Children in Clinics. A Sociological Analysis of Medical Work with Children. Tavistock Publications, London. 
Hastrup, Kirsten (1992): Det antropologiske projekt om forbløffelse. Gyldendal Intro, København.

James, Allison; Jenks, Chris; Prout, Alan (1998): Theorizing Childhood. Polity Press, London. Jenkins, Richard (1996): Social Identity. Routledge, London.

Liden, H. (1994): Barns perspektiv - de voksnes utfordring? In: Liden, Øie og Hauf (eds.): Mellom Skole og Fritid. Universitetsforlaget, Oslo.
Mayall, B. (1994): Children in Action at Home and School. In Mayall (ed): Children's Childhoods. Observed and experienced. Falmer Press, London.

McDermott, R. (1993): The acquisition of a child by learning disability. In: Chaiklin and Lave (eds.): Understanding practise. Perspectives on activity and context. Cambridge University Press.

Thorne, B. (1993): Gender Play. Girls and Boys in School. Open University Press, Buckingham. 